\title{
Deletion of IKK2 in hepatocytes does not sensitize these cells to TNF-induced apoptosis but protects from ischemia/ reperfusion injury
}

\author{
Tom Luedde, ${ }^{1}$ Ulrike Assmus, ${ }^{1}$ Torsten Wüstefeld, ${ }^{1}$ Andreas Meyer zu Vilsendorf, ${ }^{2}$ \\ Tania Roskams, ${ }^{3}$ Mark Schmidt-Supprian, ${ }^{4}$ Klaus Rajewsky, ${ }^{4}$ David A. Brenner, ${ }^{5}$ \\ Michael P. Manns, ${ }^{1}$ Manolis Pasparakis, ${ }^{6}$ and Christian Trautwein ${ }^{1}$
}

\begin{abstract}
1Department of Gastroenterology, Hepatology and Endocrinology, ${ }^{2}$ Department of Abdominal and Transplantation Surgery, Hannover Medical School, Hannover, Germany. ${ }^{3}$ Department of Pathology, University Hospitals, University of Leuven, Leuven, Belgium. ${ }^{4} \mathrm{CBR}$ Institute for Biomedical Research Inc., Harvard Medical School, Boston, Massachusetts, USA. ${ }^{5}$ College of Physicians and Surgeons, Columbia University, New York, New York, USA. ${ }^{6}$ European Molecular Biology Laboratory (EMBL), Mouse Biology Unit, Monterotondo, Italy.
\end{abstract}

\begin{abstract}
The inhibitor of NF- $\kappa B$ (I- $\kappa B)$ kinase (IKK) complex consists of 3 subunits, IKK1, IKK2, and NFF- $\mathrm{B}$ essential modulator (NEMO), and is involved in the activation of NF- $\kappa B$ by various stimuli. IKK2 or NEMO constitutive knockout mice die during embryogenesis as a result of massive hepatic apoptosis. Therefore, we examined the role of IKK2 in TNF-induced apoptosis and ischemia/reperfusion (I/R) injury in the liver by using conditional knockout mice. Hepatocyte-specific ablation of IKK2 did not lead to impaired activation of NF- $K B$ or increased apoptosis after TNF- $\alpha$ stimulation whereas conditional NEMO knockout resulted in complete block of NF- $\kappa B$ activation and massive hepatocyte apoptosis. In a model of partial hepatic I/R injury, mice lacking IKK2 in hepatocytes displayed significantly reduced liver necrosis and inflammation than wild-type mice. AS602868, a novel chemical inhibitor of IKK2, protected mice from liver injury due to $I / R$ without sensitizing them toward TNF-induced apoptosis and could therefore emerge as a new pharmacological therapy for liver resection, hemorrhagic shock, or transplantation surgery.
\end{abstract}

\section{Introduction}

NF- $\mathrm{KB}$ transcription factors are kept inactive in the cytoplasm through binding to a series of inhibitory proteins from the

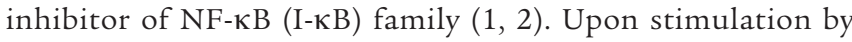
proinflammatory cytokines, I-kBs become phosphorylated at serine residues, leading to their ubiquitination and degradation by the $26 \mathrm{~S}$ proteasome. This process releases NF- $\mathrm{KB}$ from the I-KB proteins so it can translocate to the nucleus.

The high-molecular-weight complex that mediates phosphoryla-

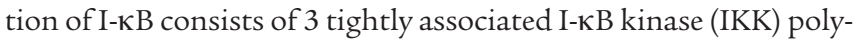
peptides; IKK1 (also called IKK $\alpha$ ) and IKK2 (IKK $\beta$ ) are the catalytic subunits and have similar primary structures (3-6). Moreover, this complex includes a regulatory subunit called NEMO (NF-KB essential modulator), IKK $\gamma$, or IKK-associated protein 1 (IKKAP-1; refs. 7-9). In vitro, IKK1 and IKK2 can form homo- and heterodimers (10). Both IKK1 and IKK2 are able to phosphorylate I-KB in vitro, but IKK2 exhibits a kinase activity higher than that of IKK1 $(5,7,11-13)$. Evidence for a functional difference between these 2 subunits comes from genetic experiments. Mice lacking Ikk1 die shortly after birth and display a phenotype marked by thickening of the epidermis as well as limb and skeletal defects $(14,15)$. In

Nonstandard abbreviations used: ALT, alanine aminotransferase; AST, aspartate aminotransferase; ConA, concanavalin A; dnIKK2Adv, dominant-negative IKK2

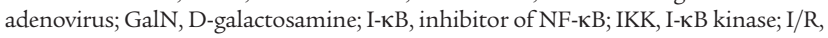
ischemia/reperfusion; LacZAdv, adenovirus expressing the LacZ protein; NEMO, $\underline{N}-\kappa B$ essential modulator; PMN, polymorphonuclear; Rb, retinoblastoma.

Conflict of interest: The authors have declared that no conflict of interest exists.

Citation for this article: J. Clin. Invest. 115:849-859 (2005)

doi:10.1172/JCI200523493. contrast, Ikk2-/- mice die in utero at approximately embryonic day 12.5 as a result of massive apoptosis in the liver, and fibroblasts from these mice show impaired activation of NF-KB in response to TNF- $\alpha$ and IL-1 (16-18). A similar phenotype was noted in mice lacking the regulatory subunit NEMO (19). Therefore, at least during embryogenesis, IKK2 and NEMO appear to be the critical IKK subunits for NF- $\mathrm{KB}$ activation and protection of liver cells from proinflammatory cytokines such as TNF- $\alpha$.

Various agents can lead to hepatocyte damage and liver failure (20). Experimental hepatic ischemia/reperfusion (I/R) injury represents a complex model that in many aspects reflects liver damage after organ transplantation, tissue resections, or hemorrhagic shock in humans. The injury detected after transient clamping of hepatic blood flow and the subsequent reperfusion lead to an excessive inflammatory response and necrotic cell death of hepatocytes. Recent studies have shown that NF-KB is activated after I/ $\mathrm{R}$ in the liver (21-23). However, the functional relevance of NF-KB activation and the role of IKK2 in hepatic I/R injury have remained unclear.

\section{Results}

Generation of conditional Ikk2 and Nemo knockout mice. Constitutive knockout mice for Ikk2 and Nemo die during embryogenesis from TNF- $\alpha$-induced hepatic apoptosis (16-19). To study the function of these respective genes in the adult mouse liver, we generated conditional knockout mice. In the Ikk2 flox mouse, exons 6 and 7 are flanked by loxP sites $\left(I k k 2^{\mathrm{f} / \mathrm{f}}\right)$. Deletion of the respective exons introduces premature termination codons, producing an Ikk2 null allele (24). The Ikk2 flox mouse (24) $\left(I k k 2^{\mathrm{f} / \mathrm{f}}\right)$ was crossed with the Alfp-cre transgenic mouse (25), which shows hepatocyte-specific 


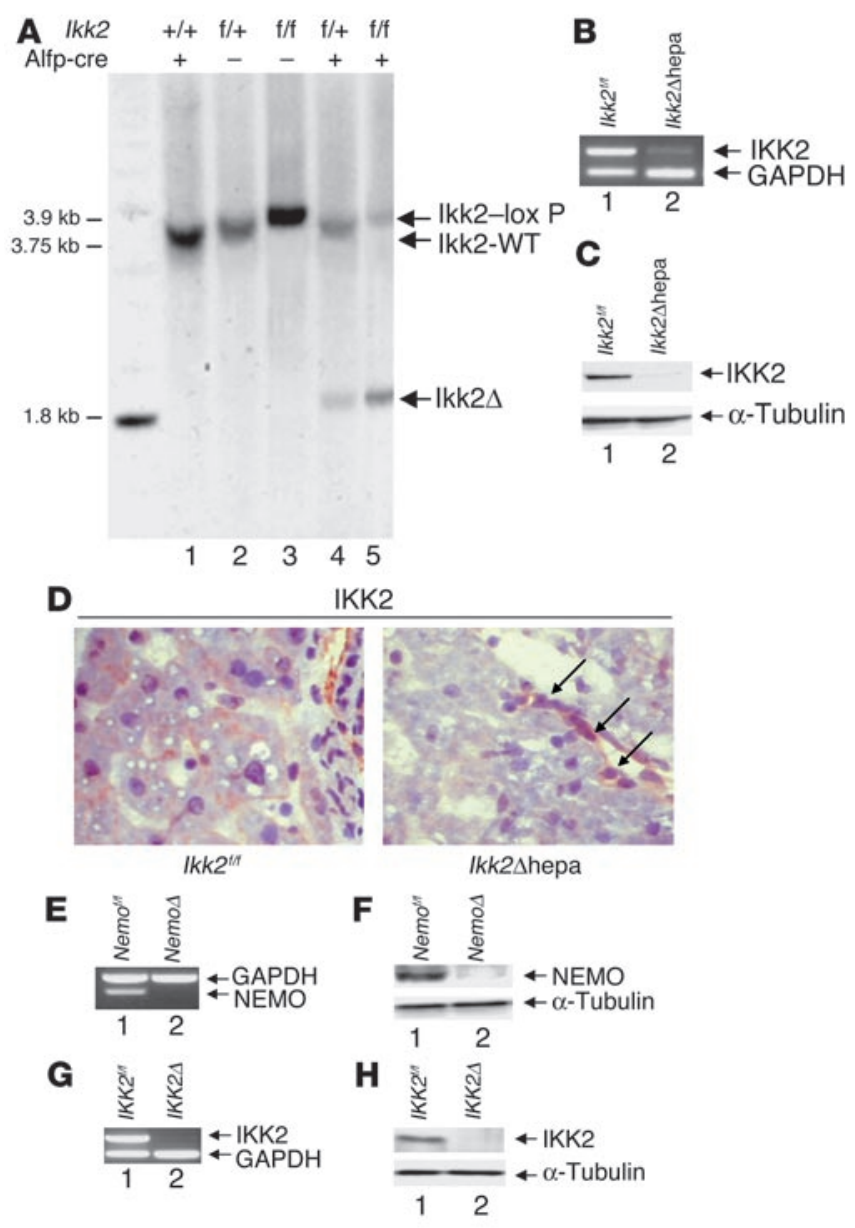

expression of Cre recombinase, to generate mice with $I k k 2$ ablated

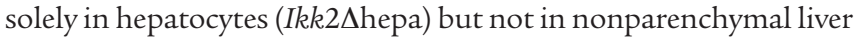
cells. I $k k 2 \Delta$ hepa mice reached adulthood without any evidence of hepatic defects. In 8-week-old mice, efficiency of Ikk2 deletion in the liver was approximately $75 \%$ to $80 \%$ (Figure 1A, lane 5), reflecting the expected ratio of parenchymal to nonparenchymal liver cells. At the RNA (Figure 1B) and protein (Figure 1C) levels, almost no IKK2 signal was detectable. To verify specificity of the IKK2 knockout, we performed an immunohistochemical analysis of IKK2 expression. As seen in Figure 1D, IKK2 is expressed in all liver cells in $I k k 2 f / f$ mice, but its expression is restricted to nonparenchymal liver cells, e.g., bile duct cells, in Ikk2 $\Delta$ hepa mice.

To compare the effects of a lack of functional IKK2 with the effects of a Nemo knockout in the liver, we crossed the Nemo ${ }^{\mathrm{f} / \mathrm{f}}$ mouse (26) with an Mx-cre mouse (27), in which the Cre-recombinase was induced by injection with poly-deoxyinosine-deoxycytodine (poly $\mathrm{I} / \mathrm{C})(\mathrm{Nemo} \Delta$ mice), which resulted in a knockout in parenchymal and nonparenchymal liver cells, and also other organs. Four days after induction, almost no NEMO could be detected in the livers at the RNA (Figure 1E) and protein (Figure 1F) levels. Whereas $I k k 2 \Delta$ hepa mice represent a developmental conditional knockout system, Nemo $\Delta$ mice are inducible conditional knockout mice. To exclude the possibility that differences in the phenotype between $I k k 2 \Delta$ hepa and $N e m o \Delta$ mice were caused by the induction with poly I/C, we also generated inducible $I k k 2^{\mathrm{f} / \mathrm{f}}-\mathrm{Mx}$-cre mice $(I k k 2 \Delta)$, which, after induction, showed an efficient knockout of Ikk2 in the liver at the RNA (Figure 1G) and protein (Figure 1H) levels.

\section{Figure 1}

Conditional knockout of $l k k 2$ and Nemo in the mouse liver. (A) Deletion in the mouse liver is shown at the DNA level by Southern blot using genomic live DNA from mice with genetic status for the floxed ( $f$ ) allele and positive $(+)$ or negative $(-)$ cre status as indicated. (B) Deletion in cre-positive floxed $l k k 2$ mice ( $l k k 2 \Delta$ hepa) was verified in comparison to cre-negative control mice $\left(I k 2^{\mathrm{ft} / \mathrm{f}}\right)$ at the RNA level by semiquantitative RT-PCR using $1 \mu \mathrm{g}$ of liver RNA and primers for IKK2 and GAPDH. (C) Western blot analysis with antibodies against IKK2 or $\alpha$-tubulin (for loading control) from $100 \mu \mathrm{g}$ of whole liver protein extracts from $I k k 2 \Delta$ hepa and $l k k 2^{\mathrm{flf}}$ mice. (D) Immunohistochemical staining of IKK2 on liver slides from $l k k 2 \Delta$ hepa and $l k k 2^{f / f}$ mice, showing that in Ikk2 $\Delta$ hepa mice, IKK2 expression is restricted to nonparenchymal liver cells such as bile duct cells (arrows). Original magnification, $\times 40$. (E) For inducible knockout of NEMO, poly I/C was injected into both cre-positive $(\mathrm{Nemo} \Delta)$ mice and cre-negative control mice $\left(\mathrm{Nemo}^{\mathrm{f} / \mathrm{f}}\right)$. Efficiency of deletion in the mouse liver is shown at the RNA level by RT-PCR. (F) Western blot analysis with antibodies against NEMO and $\alpha$-tubulin in Nemo $\Delta$ and $N e m o^{t / f}$ mice. (G) Inducible deletion of $I k k 2$. Deletion was induced by injection with poly I/C into Mx-cre-positive $(I k k 2 \Delta)$ mice and Mx-cre-negative control mice $\left(l k k 2^{\mathrm{f} / \mathrm{f}}\right)$. Efficiency of the deletion in the mouse liver is shown at the RNA level by RT-PCR. (H) Western blot for IKK2 or $\alpha$-tubulin from $I k k 2 \Delta$ and $I k k 2^{\mathrm{tff}}$ mice.

\section{IKK2 in TNF- $\alpha$-induced apoptosis in the liver}

NEMO, but not IKK2, is essential for preventing TNF- $\alpha$-induced apoptosis in the liver. TNF- $\alpha$ is a cytokine involved in mediating liver failure. It does not induce apoptosis unless cellular transcription is blocked. Previous experiments suggested that induction of antiapoptotic NF-кB target genes is critical to protecting hepatocytes from TNF- $\alpha$-dependent apoptosis (20). Mouse embryonic fibroblast cells from Ikk2 and Nemo-deficient mice showed increased sensitivity towards TNF- $\alpha$-induced apoptosis $(16,19)$. To test the function of IKK2 and NEMO in this context in the adult mouse liver, we injected TNF- $\alpha$ into $I k k 2 \Delta$ hepa mice, I $k k 2 \Delta$ mice, and $N e m o \Delta$ mice or the respective cre-negative litter mates $\left(I k k 2^{\mathrm{f} / \mathrm{f}}\right.$ and $\left.N e m o^{\mathrm{f} / \mathrm{f}}\right)$. I $k k 2 \Delta$ hepa mice as well as the control Ikk2 $2^{\mathrm{f} / \mathrm{f}}$ mice did not show any increase in alanine aminotransferases (ALTs) as a marker of hepatocyte damage (Figure 2A) nor did they display a change in survival compared to control animals during the first 24 hours after TNF- $\alpha$ injection. Similarly, I $k k 2 \Delta$ mice did not display any increase in ALT levels after TNF- $\alpha$ injection (Figure 2A). Likewise, after injection of bacterial LPS - which is a potent inducer of internal TNF- $\alpha$ - into $I k k 2 \Delta$ hepa and $I k k 2 \Delta$ mice, no change in aminotransferases or survival compared to controls was noted (data not shown). When LPS injection was combined with administration of D-galactosamine (GalN), which sensitizes hepatocytes toward TNF/LPS-induced liver injury (20), no significant difference in the course of aminotransferases could be detected between these 2 groups (Figure 2A, top right panel). In contrast, while $N e m o^{\mathrm{f} / \mathrm{f}}$ mice showed no significant ALT increase after TNF- $\alpha, N e m o \Delta$ mice displayed a massive increase in ALT levels and died between 2 and 3 hours after TNF- $\alpha$ stimulation (Figure $2 \mathrm{~A}$ ).

Histological analysis revealed no difference in the amount of TUNEL-positive cells between $I k k 2^{\mathrm{f} / \mathrm{f}}, I k k 2 \Delta$ hepa, and $N e m o^{\mathrm{f} / \mathrm{f}}$ mice before and 2 hours after TNF- $\alpha$ administration whereas TUNELpositive cells dramatically increased in Nemo $\Delta$ mice (Figure 2B). Moreover, almost no difference in caspase- 3 activity was detected between $I k k 2^{\mathrm{f} / \mathrm{f}}$ and $I k k 2 \Delta$ hepa animals during the first 6 hours after TNF- $\alpha$ administration (Figure $2 \mathrm{C}$ ). In $N e m o^{\mathrm{f} / \mathrm{f}}$ mice, caspase activity remained at baseline level whereas $N e m o \Delta$ mice responded with 

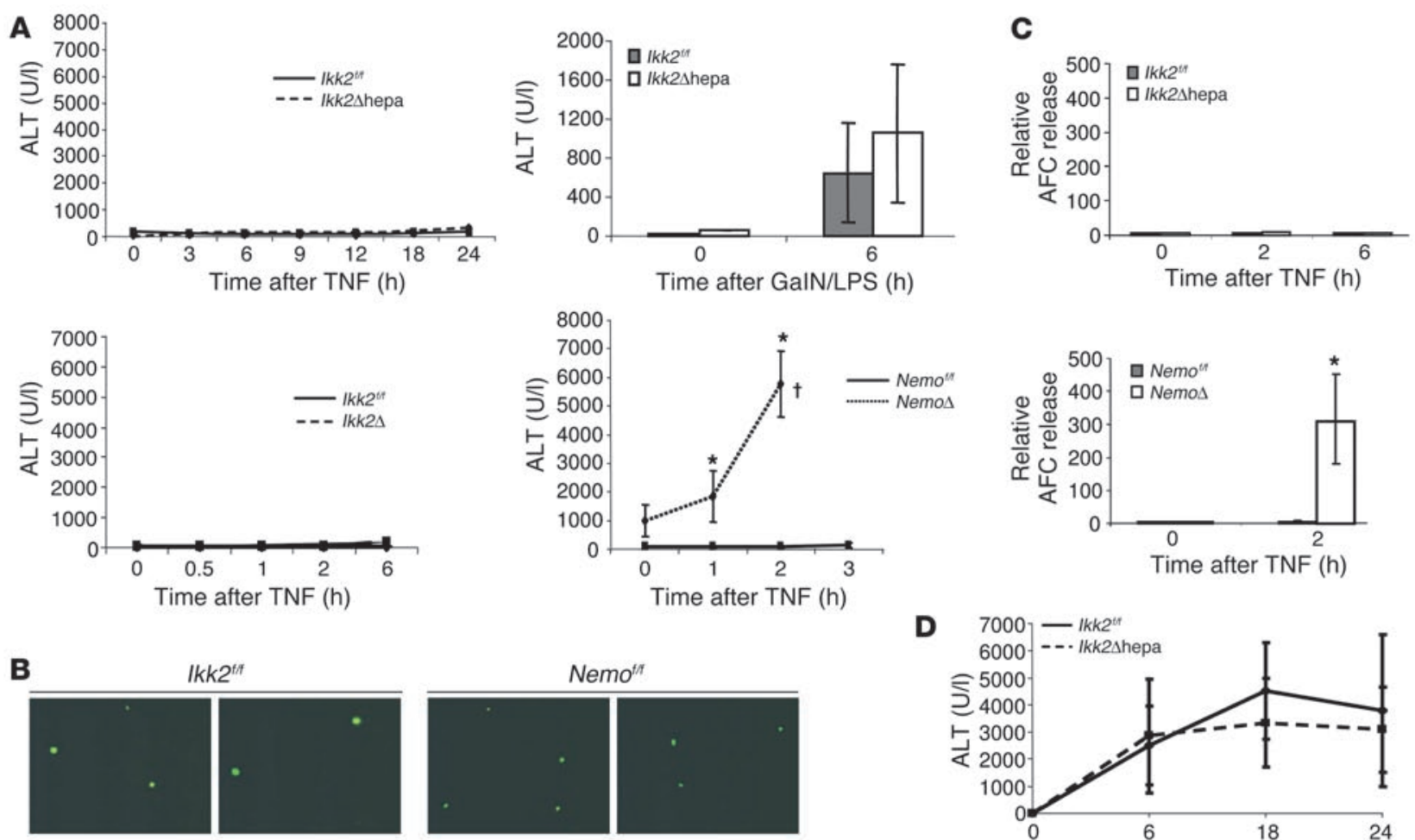

D

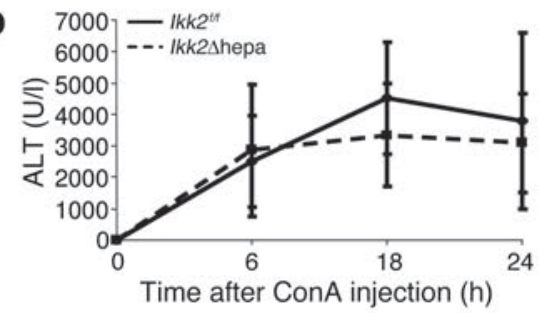

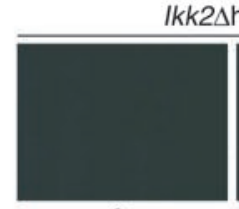

0

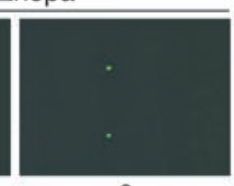

2

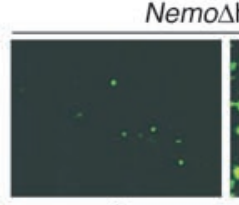

0

Time after TNF (h)

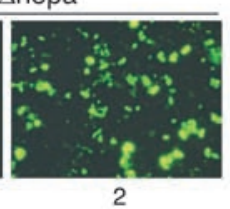

\section{Figure 2}

Nemo, but not $l k k 2$, deletion results in apoptotic cell death in the liver upon TNF- $\alpha$ stimulation. (A) $I k k 2 \Delta$ hepa, Ikk2 $\Delta$, or Nemo $\Delta$ mice and their respective control litter mates ( $/ \mathrm{kk}^{\mathrm{f} / \mathrm{f}}$ or $N$ emo $\mathrm{O}^{\mathrm{f} / \mathrm{f}}$ ) were injected intravenously with $6 \mu \mathrm{g} / \mathrm{kg}$ of recombinant TNF- $\alpha$ or intraperitoneally with LPS $(100 \mu \mathrm{g} / \mathrm{kg})$ and GalN (800 mg/kg) (right top panel). Liver injury was measured by determining ALT levels. Values are mean \pm SD for independent animals $(n=6)$. Single asterisks indicate statistical significance with $P<0.01$ versus $N e m o^{f / f}$ control mice. All Nemo $\Delta$ mice died between 2 and 3 hours after TNF- $\alpha$ stimulation from hepatic failure. (B) TUNEL staining of liver slides before and 2 hours after TNF- $\alpha$ stimulation showing clear positive staining in Nemo $\Delta$, but not in Ikk2 4 hepa mice. Results are representative of those obtained in mice $(n=6)$. Original magnification, $\times 40$. (C) Detection of caspase 3-like activity by an enzymatic, fluorometric assay from whole liver protein lysates at different time points after TNF- $\alpha$ stimulation in Ikk2 $\Delta$ hepa, Nemo $\Delta$, and control littermates. Values are mean \pm SD for independent animals $(n=6)$. (D) ALT levels as markers for liver injury at different time points following ConA injection into $l k k 2 \Delta$ hepa and $I k k 2^{f / f}$ mice. Values are mean \pm SD for independent animals $(n=6)$. (E) ALT levels following Fas-stimulating Jo-2 injection into $l k k 2 \Delta$ hepa and $I k k 2^{\mathrm{t} / \mathrm{f}}$ mice. Values are mean \pm SD for independent animals $(n=6)$. U/l, units per liter; AFC, 7-amino-trifluoromethyl coumarin.

a strong increase in caspase-3-like activity 2 hours after TNF- $\alpha$. Thus, absence of functional IKK2 in the adult mouse liver does not sensitize this organ to TNF- $\alpha$-induced apoptosis, but lack of the NEMO subunit leads to massive hepatic apoptosis and liver failure upon TNF- $\alpha$ stimulation.

Concanavalin A (ConA) administration, which causes indiscriminate activation of $\mathrm{T}$ cells in the liver, results in acute hepatitis in rodents, which is accompanied by massive hepatocyte apoptosis (28). ConA stimulation in mice leads to TNF- $\alpha$-dependent activation of NF-кB (29). Therefore, we tested to see whether IKK2 deficiency might influence susceptibility to ConA-induced liver damage. As shown in Figure 2D, Ikk2 $\Delta$ mice and $I k k 2^{\mathrm{f} / \mathrm{f}}$ mice did not differ in liver injury following ConA administration, which underlines the fact that IKK2-dependent signals are not essential for prevention of $\mathrm{T}$ cell-driven liver apoptosis. To evaluate a possible difference in Fas-mediated liver failure between these two groups, we injected the anti-Fas Jo- 2 antibody into I $k 2 \Delta$ hepa mice and $I k k 2^{\mathrm{f} / \mathrm{f}}$ mice (Figure $2 \mathrm{E}$ ). Again, no significant difference in liver injury was seen between both groups, suggesting no major influence of the IKK2 subunit on Fas signaling in the liver.

$T N F-\alpha$ dependent $N F-\kappa B$ activation in the liver can occur independently of IKK2 but is dependent on functional NEMO. Given the dramatic difference in the sensitivity toward TNF- $\alpha$-induced apoptosis, we wondered if this phenotype correlates with the activation of $\mathrm{NF}-\kappa \mathrm{B}$ in this model. We used nuclear protein extracts from whole mouse livers after TNF- $\alpha$ stimulation and performed gel- 

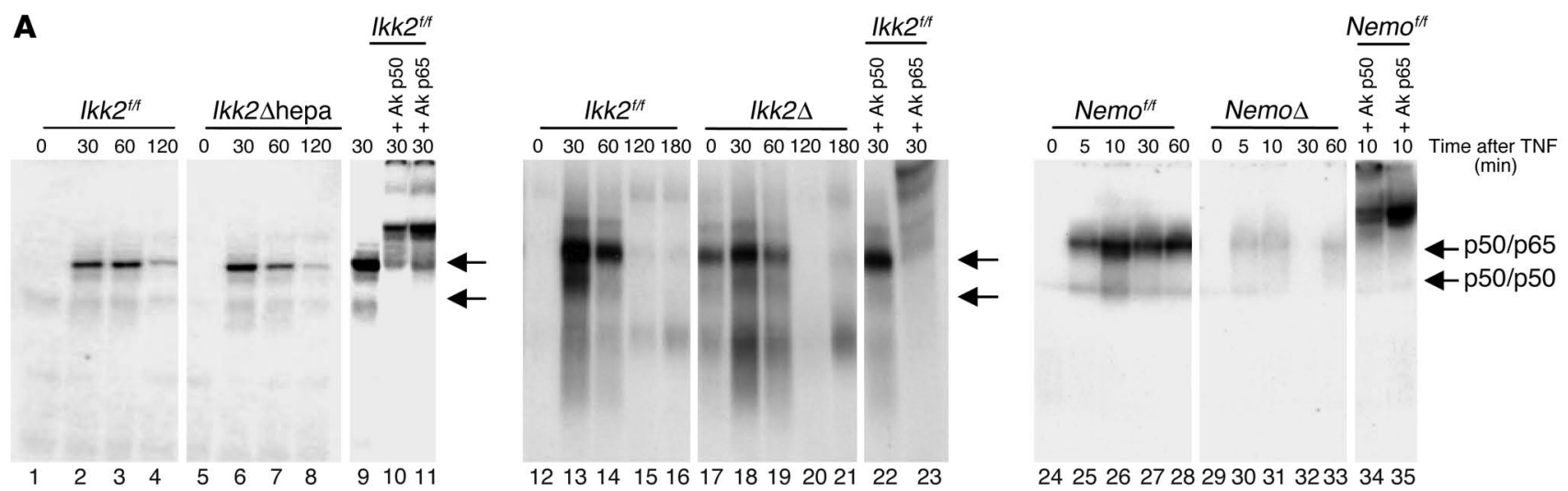

B

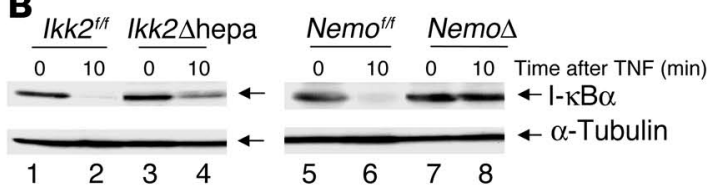

C
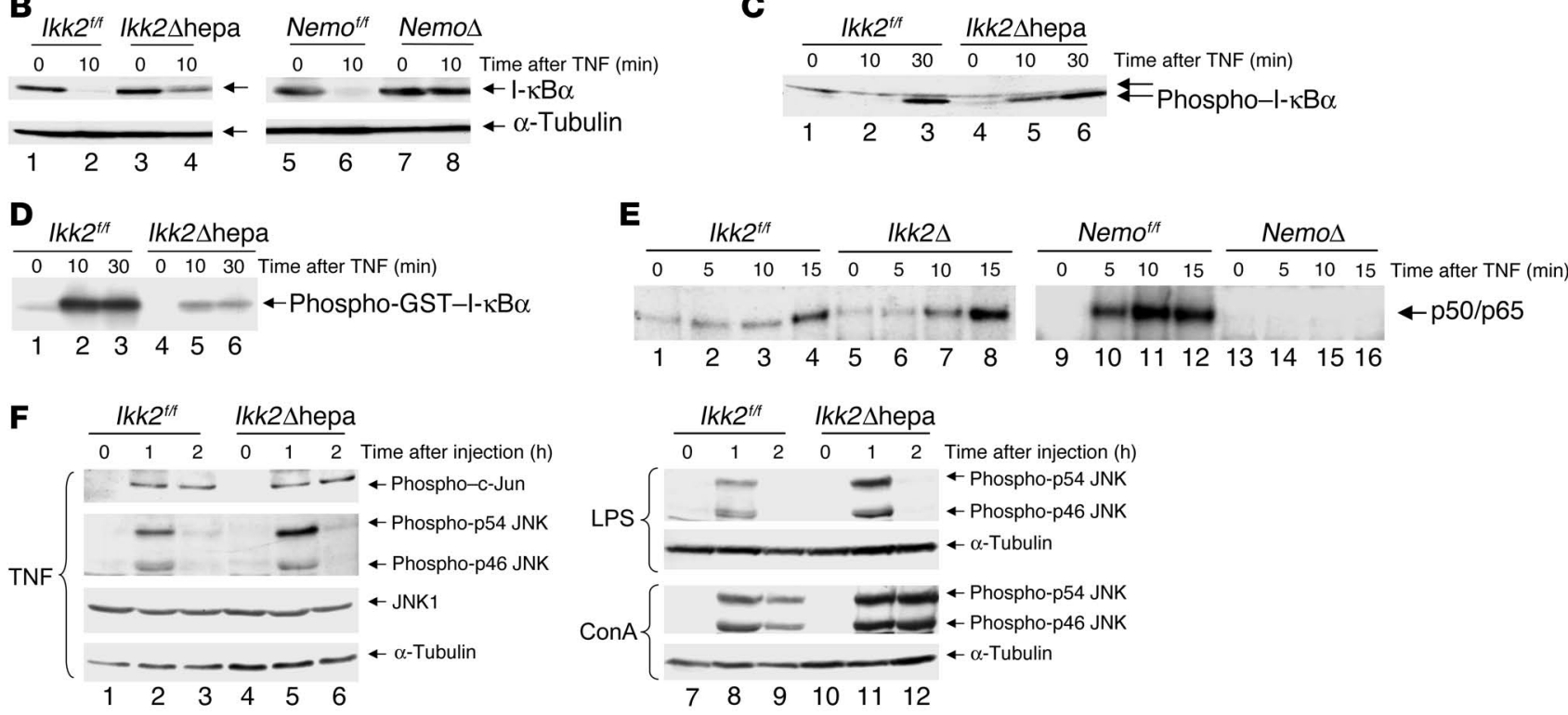

Figure 3

NF-kB activation in the liver upon TNF- $\alpha$ stimulation is blocked in mice lacking Nemo but not lkk2. (A) Liver nuclear protein extracts $(5 \mu \mathrm{g})$ from the indicated mice and time points after TNF- $\alpha$ stimulation were subjected to a gel-retardation assay with an NF-kB consensus probe. In lanes $10 / 22 / 34$ and 11/23/35, antibodies for the NF-KB subunits p50 or p65 were added as indicated as supershift control. The figure depicts results from 3 different assays. (B) l-kB $\alpha$ degradation in the different mouse groups was assessed by Western blot analysis with $50 \mu \mathrm{g}$ of whole cell

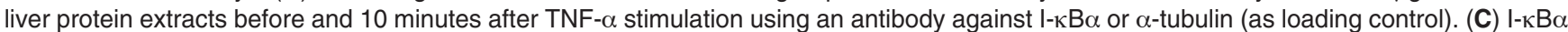
phosphorylation was detemined after TNF- $\alpha$ stimulation by subjecting $50 \mu \mathrm{g}$ of proteins to a Western blot analysis with an antibody detecting I-אB $\alpha$ phosphorylated at Ser32. (D) Evaluation of IKK activity. Proteins $(300 \mu \mathrm{g})$ from mice stimulated with TNF- $\alpha$ were IP with a Nemo-antibody and subjected to a kinase assay using a truncated glutathione-S-transferase-I-kB $\alpha(1-54)$ protein as substrate. (E) Gel-retardation assay with an NF-kB consensus site using $5 \mu \mathrm{g}$ of nuclear protein extracts from primary hepatocyte cultures. Results are representative of those obtained in mice $(n=4)$. (F) JNK activity was measured by Western blot using protein from mice stimulated with TNF, LPS, and ConA as indicated. Antibodies detecting c-Jun phosphorylated at Ser63 or JNK phosphorylated at Thr183/Tyr185 as well as nonphosphorylated JNK1 and $\alpha$-tubulin as loading control were used.

retardation assays. As shown in Figure 3A, Ikk2 $\Delta$ hepa mice exhibited no difference in the intensity and timing of NF-кB DNA binding compared with that shown in controls by gel-retardation assays, which was also the case in Ikk2 $\Delta$ mice. In contrast, NF- $\mathrm{kB}$ activation was almost completely inhibited in the Nemo $\Delta$ mice. I- $\kappa \mathrm{B} \alpha$ degradation after TNF- $\alpha$ stimulation measured by Western blot analysis was clearly detected in both $I k k 2 \Delta$ and $I k k 2^{\mathrm{f} / \mathrm{f}}$ mice 10 minutes after TNF- $\alpha$ whereas in Nemo $\Delta$ mice, it was almost completely blocked (Figure 3B).

We next examined the kinase activity of the IKK complex in $I k k 2 \Delta$ hepa and $I k k 2^{\mathrm{f} / \mathrm{f}}$ mice using a truncated I- $\mathrm{kB}$ protein as sub- strate (Figure 3C). In line with previous in vitro results $(5,11-13$, 30 ), kinase activity in mice lacking IKK2 was weaker than in wildtype mice. Nevertheless, when we analyzed the phosphorylation status of internal I- $\mathrm{KB} \alpha$, no difference between the 2 groups could be detected (Figure 3D). These results were confirmed in hepatocyte cultures to exclude the possibility that the observed NF-KB activation in livers from Ikk2-deficient mice was occurring solely in cells that might have incompletely knocked out the respective gene. Primary hepatocytes were cultured from Ikk2 $\Delta$ and $N e m o \Delta$ mice as well as the cre-negative control animals, and NF-KB activation was measured by gel-retardation assay (Figure 
A

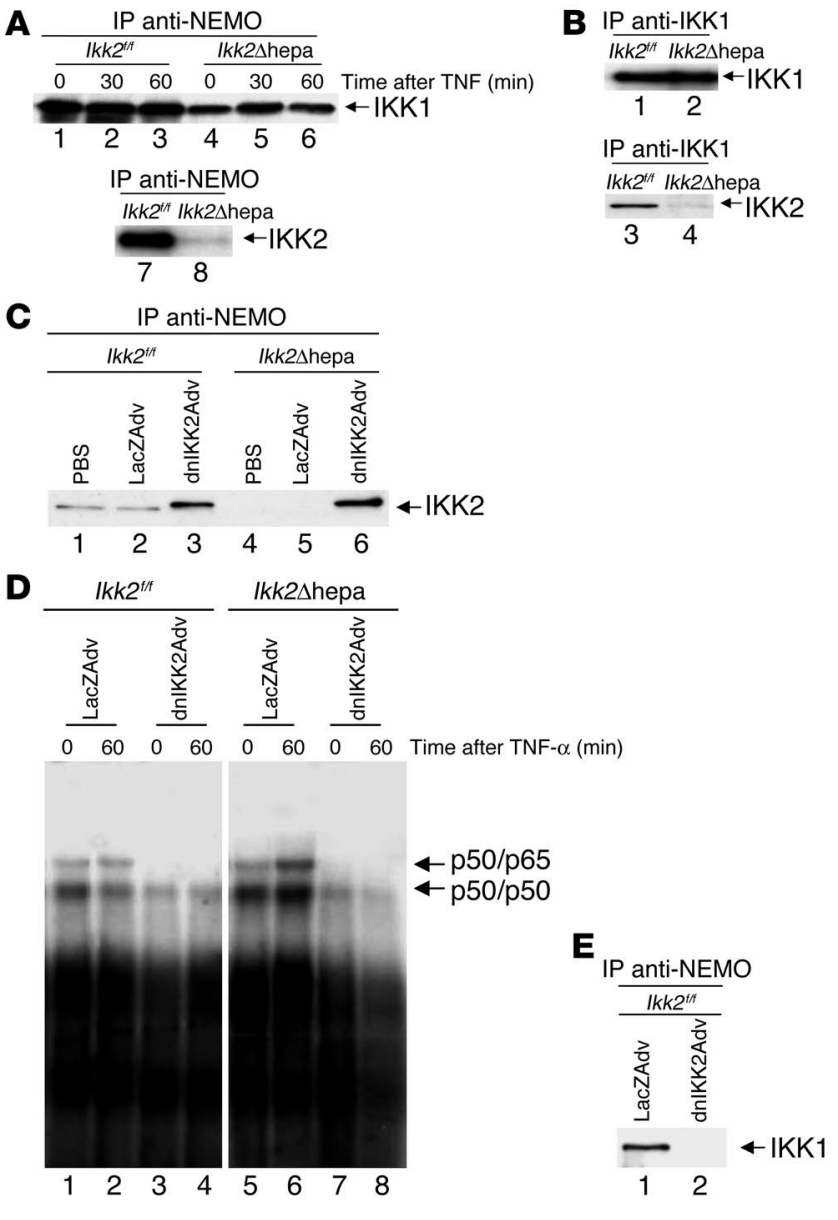

3E). Again, no difference in NF- $\mathrm{kB}$ activation was noted between hepatocytes from $I k k 2 \Delta$ and $I k k 2^{\mathrm{ff} / \mathrm{f}}$ control mice whereas NF-KB was blocked in primary hepatocytes from Nemo $\Delta$ mice. Therefore, although IKK activity is attenuated in the absence of IKK2, it is sufficient to fully activate NF- $\mathrm{KB}$ in response to TNF- $\alpha$ whereas this is not the case in the absence of NEMO. Moreover, the ability of the IKK complex to activate NF-KB appears to correlate strictly with its antiapoptotic role in TNF- $\alpha$ signaling.

JNK is activated upon cellular stress, including TNF- $\alpha$-signaling (20). We tested to see whether JNK activation is preserved in Ikk2 knockout mice. As shown in Figure 3F, both p46- and p54-JNK phosphorylation, which are essential steps for JNK activation, and c-jun phosphorylation were almost equally induced after TNF stimulation in both groups. The same result was seen after LPS and ConA administration with a slightly enhanced signal in Ikk2 $\Delta$ hepa mice. Therefore, crosstalk between the NF-KB and JNK pathway does not strictly depend on IKK2.

A dominant-negative IKK2 mutant can block NF- $\mathrm{K} B$ activation in Ikk2 $\Delta$ hepa mice. Our finding that NF-KB can be activated independently of IKK2 is surprising with regard to previous results in hepatocyte cultures (31). In this study, an adenoviral vector expressing a dominant-negative form of IKK2 with a mutation in the kinase domain but not a dominant-negative IKK1 adenovirus completely blocked TNF- $\alpha$-dependent NF- $\kappa B$ activation, which suggests that this process is mediated primarily via IKK2. To examine this more closely, we first characterized the binding of

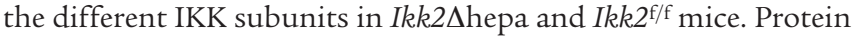

\section{Figure 4}

A dominant-negative IKK2 form can block NF-кB activation after TNF- $\alpha$ stimulation. (A) IP in $300 \mu \mathrm{g}$ of whole cell liver protein extracts from $/ \mathrm{kk} 2^{\mathrm{ft} / \mathrm{f}}$ and $l k k 2 \Delta$ hepa mice was performed with a polyclonal antibody against NEMO, followed by Western blot analysis with a monoclonal antibody against IKK1 or IKK2 as indicated. Association between NEMO and IKK1 was assessed before as well as 30 and 60 minutes after stimulation with TNF- $\alpha$. (B) Western blot of protein extracts that were IP with anti-IKK1 and blotted with a monoclonal antibody against IKK1 or IKK2 as indicated. (C) Primary hepatocyte cultures were prepared from livers of $I k k 2^{t / f}$ and $l k k 2 \Delta$ hepa mice and either treated with PBS alone, infected with LacZAdv, or infected with dnIKK2Adv in a viral dose of 20 PFUs for 12 hours. Protein extracts $(200 \mu \mathrm{g})$ were subjected to IP with a NEMO antibody, followed by Western blot with an IKK2 antibody. (D) Primary hepatocytes from $l k k 2^{\mathrm{tff}}$ and $l k k 2 \Delta$ hepa mice were infected with LacZAdv or dnIKK2Adv in a viral dose of 20 PFUs for 12 hours and treated with TNF- $\alpha(30 \mathrm{ng} / \mathrm{ml})$. Protein extracts were subjected to an NF-KB gel-retardation assay. (E) Protein extracts $(100 \mu \mathrm{g})$ from primary hepatocytes infected with LacZAdv or dnIKK2Adv were IP with anti-Nemo and blotted with a monoclonal antibody against IKK1.

extracts IP with a NEMO antibody showed that IKK1 could still be detected in the complex. As expected, no IKK2 was detectable in the IKK complex in Ikk2 $2 \Delta$ mice (Figure 4A). IP with an IKK1 antibody showed equal amounts of IKK1 in the IKK complex in both groups (Figure 4B).

To test whether expression of dominant-negative IKK2 would eliminate the remaining NF- $\mathrm{KB}$ activation in hepatocytes lacking IKK2, we infected hepatocyte cultures from $I k k 2 \Delta$ and $I k k 2^{\mathrm{f} / \mathrm{f}}$ mice with a dominant-negative IKK2 adenovirus (dnIKK2Adv) with a mutation in the kinase domain at position 44 (31). As a control, we used an adenovirus expressing the LacZ protein (LacZAdv). When $\mathrm{dnIKK} 2 \mathrm{Adv}$ was added to cells from $I k k 2^{\mathrm{f} / \mathrm{f}}$ and $I k k 2 \Delta$ mice, a strong IKK2 signal was seen in both groups after co-IP with an anti-NEMO antibody. This signal was detected slightly above the wild-type signal due to a flag tag (Figure 4C, Lanes 3 and 6). Thus, the externally expressed IKK2dn-mutant form was integrated into the IKK complex. We then stimulated these hepatocyte cultures with recombinant TNF- $\alpha$ and measured NF- $\kappa B$ activation in a gelretardation assay. NF- $\kappa$ B DNA binding was induced 60 minutes after TNF- $\alpha$ stimulation in both groups when cells were treated with the control virus (Figure 4D). In contrast, NF-кB activation was completely blocked in cells from $I k k 2^{\mathrm{f} / \mathrm{f}}$ and $I k k 2 \Delta$ mice infected with dnIKK2Adv. To test whether IKK1 is still recruited to the IKK complex in the presence of the dominant-negative IKK2 virus, we performed another Nemo/IKK1 co-IP on wild-type extracts from hepatocytes infected with the control virus and dnIKK2Adv. As clearly demonstrated in Figure 4E, no IKK1 signal is detected when the mutant IKK2 protein is overexpressed. These experiments provide a mechanistic explanation for the different phenotypes seen with the dnIKK2Adv and the Ikk2 knockout animals. The IKK1/Nemo complex is apparently sufficient to fully activate $\mathrm{NF}-\kappa \mathrm{B}$ in the absence of IKK2. In contrast, overexpression of the mutant IKK2 form prevents recruitment of IKK1 to the protein complex, which results in a nonfunctional IKK complex.

\section{IKK2 in bepatic I/R injury}

IKK2-dependent signaling in hepatocytes mediates liver damage in an $I / R$ model. Previously we examined the role of IKK2 and NF- $\kappa B$ in the TNF- $\alpha$ pathway. NF- $\kappa \mathrm{B}$ is also activated in other experimental models of liver injury. We evaluated the relevance of IKK2- 

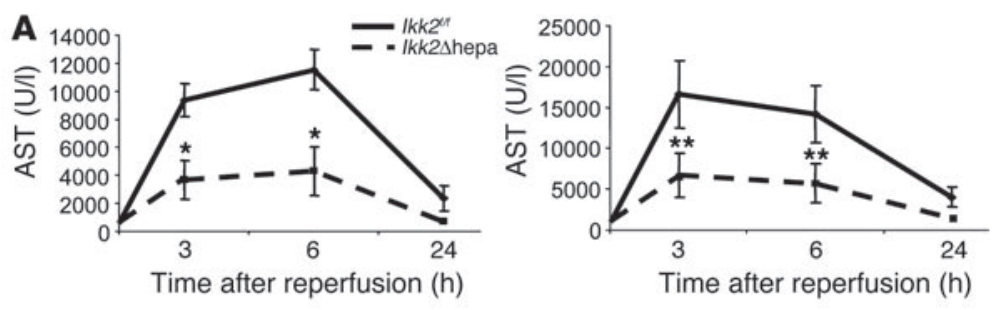

B

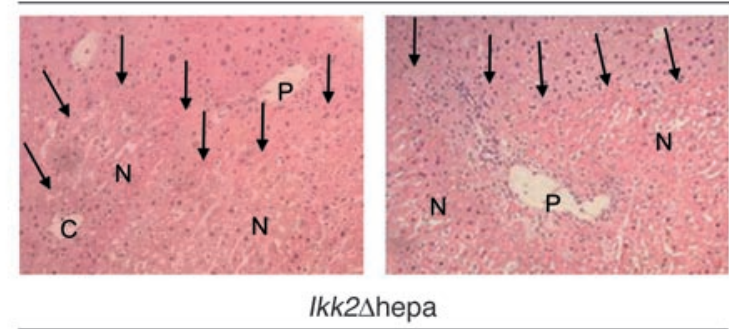

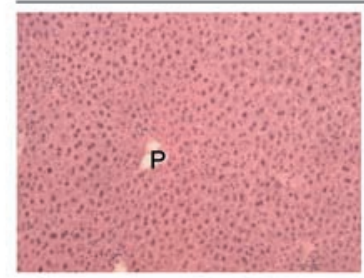

6 Time after reperfusion $(\mathrm{h})$

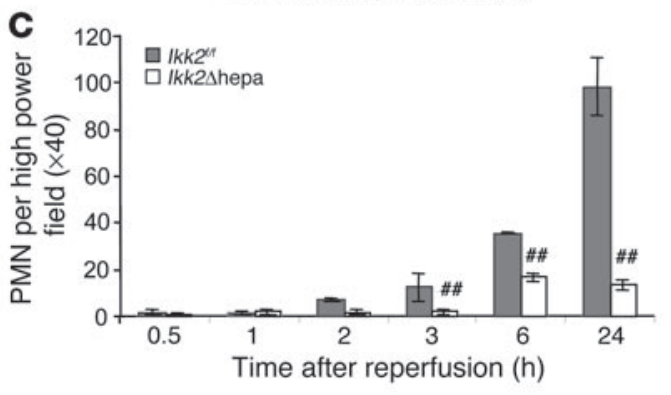

dependent signaling in the liver after $\mathrm{I} / \mathrm{R}$. The degree of hepatic injury after 60 minutes I/R was measured as an increase in aspartate aminotransferases (ASTs) and ALT (Figure 5A). Unexpectedly, Ikk2 $\Delta$ hepa animals showed significantly lower levels of both AST and ALT at 3 and 6 hours after I/R than $I k k 2^{\mathrm{f} / \mathrm{f}}$ mice. On histological analysis, $I k k 2^{\mathrm{f} / \mathrm{f}}$ mice clearly displayed necrotic cell damage 6 hours and 24 hours after reperfusion, which was significantly reduced at both time points in Ikk2 $\Delta$ hepa animals (Figure 5B). In both groups, no signs of apoptosis - measured by TUNEL test and caspase-3-like activation - could be detected (data not shown).

Inflammation and infiltration with polymorphonuclear (PMN) leukocytes is another process that occurs during liver injury after I/R (32). We found that infiltration with PMN leukocytes after reperfusion was significantly reduced in $I k k 2 \Delta$ hepa mice compared with $I k k 2^{\mathrm{f} / \mathrm{f}}$ control mice (Figure 5C). Therefore, IKK2-dependent signaling does play a role in hepatic I/R injury. In fact, in contrast to other models of liver injury where IKK-dependent signaling plays a protective role, IKK2 mediates necrosis and inflammation after I/R, and hepatocyte-specific knockout of the Ikk2 gene is protective in this context.

\section{Figure 5}

Ikk2 deletion in hepatocytes protects against liver injury and inflammation after hepatic I/R. (A) Ikk2 $\Delta$ hepa and $I k k 2^{f / f}$ control mice underwent a procedure of partial hepatic ischemia lasting for 60 minutes, which was followed by reperfusion. Serum AST and ALT levels were measured at the indicated time points before the procedure and after reperfusion as markers for liver injury. Values are mean \pm SD for independent animals $(n=8)$. Asterisks indicate statistical significance: ${ }^{*} P<0.02$ versus $l k k 2^{\mathrm{t} / \mathrm{f}}$ control mice; ${ }^{* \star} P<0.05$ versus $l k k 2^{\mathrm{t} / \mathrm{f}}$ control mice. (B) H\&E staining of liver slides from $I k k 2^{\mathrm{t} / \mathrm{f}}$ and Ikk2 $\Delta$ hepa mice at 6 hours and 24 hours after reperfusion. $N$, necrotic area (arrows indicate margins of necrotic areas; $P$, portal vein; $C$, central vein. Results are representative of those obtained in 8 mice. Original magnification, $\times 20$. The area of necrotic parenchymal surface was measured and quantified (right panel). Values are mean \pm SD for independent animals $(n=4)$. Hatch mark indicates statistical significance: $P<0.01$ versus $I k 2^{\mathrm{t} / \mathrm{f}}$ control mice. (C) Quantification of PMN leukocytes per high power field $(\times 40)$ at different time points after reperfusion. Values are mean \pm SD for independent animals $(n=4)$. Double hatch marks indicate statistical significance: $P<0.001$ versus $l k k 2^{\mathrm{fff}}$ control mice.

Activation of NF-КB DNA binding and induction of $N F-\kappa B$ target genes after $I / R$ is dependent on functional IKK2. Recent studies have suggested that during I/R injury, $\mathrm{NF}-\kappa \mathrm{B}$ is activated independently of the IKK complex by alternative I- $\kappa \mathrm{B} \alpha$ tyrosine phosphorylation by Src family kinases $(21,33)$. I $k k 2 \Delta$ hepa mice are protected from liver damage after I/R compared with wild-type mice. We evaluated how the observed phenotype correlated with NF- $\kappa \mathrm{B}$ activation in the liver. In $I k k 2^{\mathrm{f} / \mathrm{f}}$ mice, NF-кB DNA-binding was detected already at 30 minutes and peaked at 60 minutes after reperfusion (Figure 6A). In contrast, NF-кB activation was almost completely blocked in $I k k 2 \Delta$ hepa mice.

iNOS is a known NF- $\mathrm{BB}$ target gene that regulates $\mathrm{NO}$ metabolism and plays a role in liver injury after $\mathrm{I} / \mathrm{R}(2,32)$. In contrast to $I k k 2^{\mathrm{f} / \mathrm{f}}$ mice, no iNOS-positive cells were detected in Ikk2 $\Delta$ hepa mice 6 hours after reperfusion (Figure 6B). TNF- $\alpha$, another NF- $\mathrm{KB}$ target, has been shown to be a key cytokine in I/R injury (34). On histological analysis, we found that TNF- $\alpha$ expression in liver cells was significantly reduced in Ikk2 $\Delta$ hepa mice (Figure 6C).

Kupffer cells play a central role in mediating liver injury after $\mathrm{I} / \mathrm{R}$. To ensure that these cells are functionally active in Ikk2 $\Delta$ hepa mice, Kupffer cells were isolated from $I k k 2^{\mathrm{f} / \mathrm{f}}$ and $I k k 2 \Delta$ hepa mice (Figure 6D). Cells were stained with an antibody against the F4/80 antigen, which is a macrophage-specific marker, to verify the specificity of the preparation procedure. As expected, IKK2 expression was not abolished in Ikk2 $\Delta$ hepa mice, underlining the restriction of the knockout to hepatocytes. Moreover, TNF- $\alpha$ expression in response to LPS stimulation was comparable in both Ikk2 $\Delta$ hepa and control mice, indicating that the observed phenotype was not caused by a possible Ikk2 knockout in Kupffer cells.

Pharmacological inhibition of IKK2 as a new therapentic approach for prevention of liver injury after $I / R$. Hepatic I/R injury is a major problem and determines to a high degree the morbidity and mortality associated with liver surgery under vascular exclusion (Pringle maneu- 


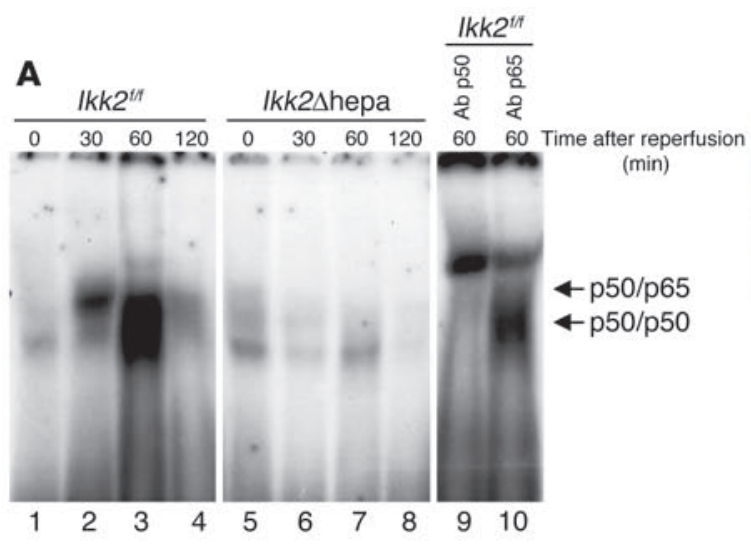

B

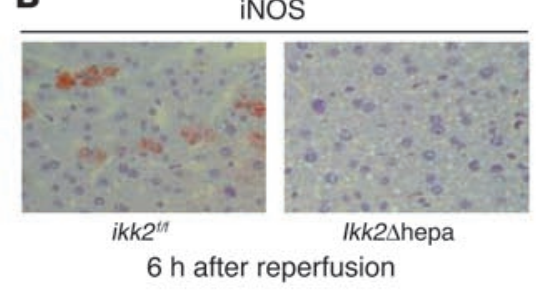

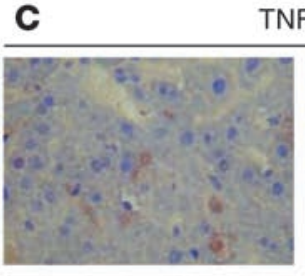

$I k k 2^{\text {n }}$ $6 \mathrm{~h}$ after reperfusion

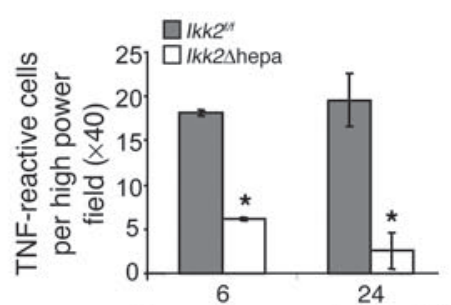

Time after reperfusion (h)
D
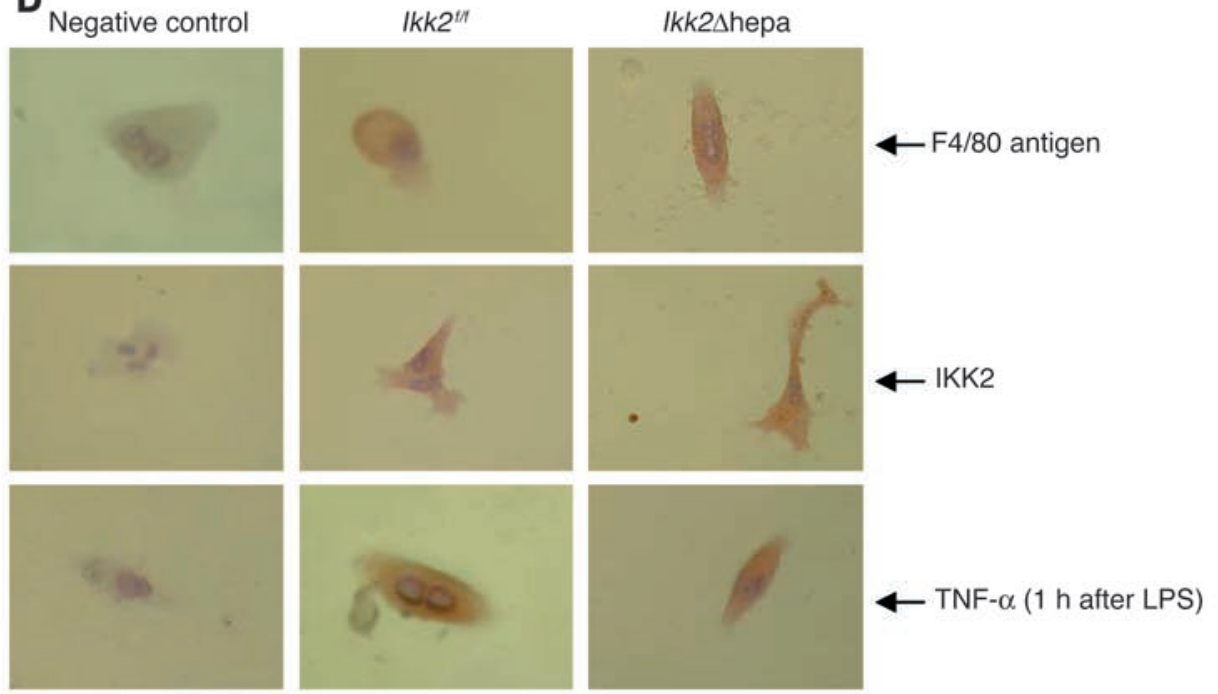

\section{Figure 6}

Activation of NF- $\mathrm{KB}$ and induction of NF-KB target genes after $\mathrm{I} / \mathrm{R}$ is dependent on functional IKK2. (A) Nuclear protein extracts $(5 \mu \mathrm{g})$ from livers of $I \mathrm{kk}^{\mathrm{f} / \mathrm{f}}$ and Ikk2 $\Delta$ hepa mice at different time points after I/R were subjected to a gel-retardation assay with an NF-KB consensus oligonucleotide. In lanes 9 and 10, antibodies for the NF- $\kappa B$ subunits p50 or p65 were added as supershift control. (B) Immunohistochemical staining for iNOS at 6 hours after $\mathrm{I} / \mathrm{R}$ in $/ \mathrm{kk}^{\mathrm{ft/f}}$ and $l k k 2 \Delta$ hepa mice. Original magnification, $\times 40$. Results are representative of those obtained in mice $(n=4)$. (C) Immunohistochemical staining for TNF- $\alpha$ at 6 hours after I/R. Original magnification, $\times 40$. The number of TNF- $\alpha$-positive cells was quantified (right panel). Values are mean \pm SD for independent animals $(n=4)$. The asterisk indicates statistical significance: $P<0.01$ versus $1 \mathrm{kk}^{\mathrm{f} / \mathrm{f}}$ control mice. (D) Kupffer cells were isolated from livers of $l k k 2^{t / f}$ and Ikk2 2 hepa mice and stained with an antibody against the $\mathrm{F} 4 / 80$ antigen, which is a macrophage-specific marker, to verify the specificity of the preparation procedure. Equal expression of IKK2 was verified by staining with a polyclonal antibody against IKK2. Cells were stimulated with $1 \mu \mathrm{g} / \mathrm{ml}$ LPS for 1 hour and TNF- $\alpha$ expression examined by immunohistochemical staining to prove that Kupffer cells in the livers of $l k k 2 \Delta$ hepa mice are functionally active. Original magnification, $\times 400$. For negative control, no primary antibody was added. ver), transplantation surgery, or hemorrhagic shock. Therefore, it is important to discover new ways for pharmacological intervention to improve the clinical outcome in these settings. AS602868 is a new, reversible, and ATP-competitive inhibitor of IKK2 (35). Wildtype mice received an oral administration of AS602868 20 hours and 2 hours before intervention whereas in the control group, mice received only the vehicle substance. Correlating with the results in I kk2 $\Delta$ hepa mice, pharmacological inhibition of IKK2 in the absence of liver injury or after pure TNF- $\alpha$ stimulation had no effect on survival or the course of aminotransferases, as depicted in Figure $7 \mathrm{~A}$ for ALT levels. Moreover, NF- $\mathrm{KB}$ activation after pharmacological inhibition of IKK2 was not impaired after TNF- $\alpha$ stimulation, again supporting the results found in the conditional Ikk2 knockout mice (Figure 7B). In the I/R model, mice treated with the IKK2 inhibitor showed a dramatic decrease in AST and ALT levels compared with the control group 6 hours after reperfusion (Figure 7C), which was even more pronounced than seen before in the Ikk2 $\Delta$ hepa animals. Histological analysis revealed a clear attenuation of necrosis and neutrophilic infiltration after AS602868 treatment (Figure 7, D and E). These results indicate a potential benefit of pharmacological IKK2 inhibition in the prevention of liver injury after I/R.

\section{Discussion}

We demonstrate that in the adult mouse liver NF-кB can be activated independently of IKK2 and that a hepatocyte-specific knockout of the Ikk2 gene does not lead to increased apoptosis upon TNF- $\alpha$ stimulation. This result contrasts with the phenotype seen in constitutive Ikk2 knockout mice, which die during embryogenesis due to TNF- $\alpha$-induced liver degeneration (16-18). The fact that our floxed $I k k 2^{\mathrm{f} / \mathrm{f}}$ mouse resembles the phenotype of 

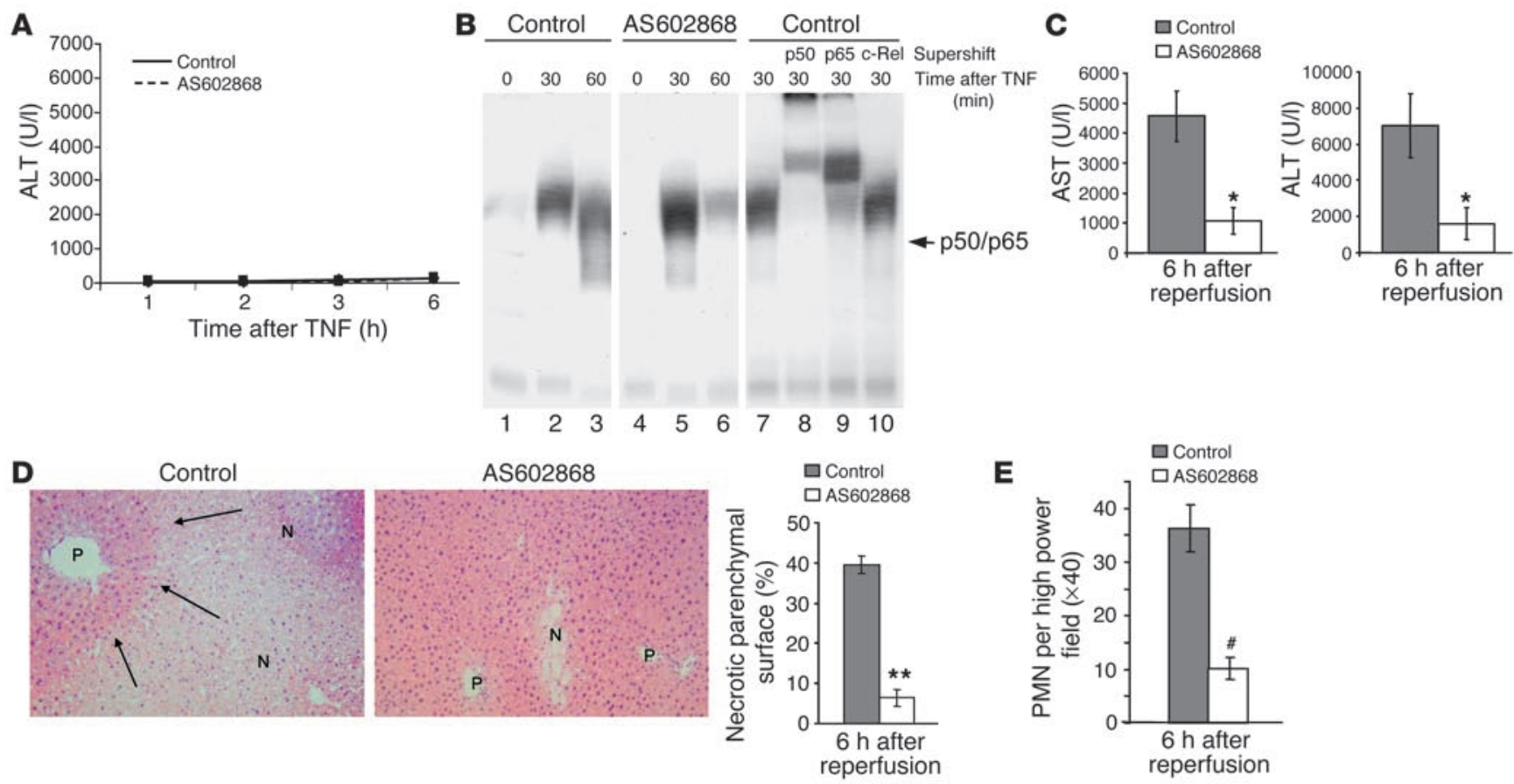

\section{Figure 7}

The pharmacological IKK2 inhibitor AS602868 protects mice from liver injury due to hepatic I/R. (A) C57BL6 mice received an oral administration of $150 \mu \mathrm{l}$ of the IKK2 inhibitor AS602868 (10 $\mu \mathrm{g} / \mathrm{g}$ body weight) or the vehicle substance (control) at 20 hours and 2 hours before stimulation with $6 \mu \mathrm{g} / \mathrm{kg}$ recombinant TNF- $\alpha$. Evaluation of serum ALT levels at the indicated time points after TNF- $\alpha$ stimulation showing no significant difference between treated and untreated animals. (B) NF-кB EMSA using $5 \mu \mathrm{g}$ of nuclear protein extracts from animals treated with AS602868 or control. (C) Serum AST and ALT levels were measured at the indicated time points after reperfusion in mice that were pretreated with AS602868 or vehicle substance (control) and had undergone partial I/R. Values are mean \pm SD for independent animals $(n=4)$. The asterisk indicates statistical significance with $P<0.05$ versus control mice. (D) H\&E staining of liver slides at 6 hours after reperfusion from control mice and mice treated with AS602868. Original magnification, $\times 20$. The area of necrotic parenchymal surface was measured and quantified (right panel). Values are mean \pm SD for independent animals $(n=4)$. The double asterisk indicates statistical significance with $P<0.01$ versus control mice. (E) Quantification of PMN leukocytes per high power field $(\times 40)$ at 6 hours after reperfusion. Values are mean \pm SD for independent animals $(n=4)$. The hatch mark indicates statistical significance with $P<0.001$ versus control mice.

the Ikk2 constitutive knockout mouse when crossed with a general cre deleter strain (24) argues for the 2 different functions of IKK2 in development and adult organism. Therefore, it appears that in the adult mouse hepatocyte, other molecules can mediate TNF- $\alpha$-induced NF- $\kappa \mathrm{B}$ activation. A similar phenomenon has recently been observed in another study, which demonstrated that acute loss of retinoblastoma-gene (Rb-gene) function by conditional knockout has phenotypic consequences different from those of germline loss of Rb, explained in part by functional compensation by the Rb-related gene p107 (36).

Our results indicating that lack of NEMO completely blocks NF- $\kappa \mathrm{B}$ activation argues against the possibility that NF- $\kappa \mathrm{B}$ activation occurs independently of the IKK complex. It is likely that IKK1 can functionally replace IKK2 in this model. We show that, although IKK activity toward its substrate, $\mathrm{I}-\kappa \mathrm{B}$, is weaker in the absence of IKK2, this activity is sufficient to fully activate NF- $\mathrm{B}$ in this model. We show that the overexpressed IKK2 with a mutation in its kinase domain is integrated into the IKK complex and prohibits access of IKK1 to the complex, which leads to a complete block in NF- $\kappa \mathrm{B}$ activation. These findings strongly support the assumption that IKK1 can functionally replace IKK2 in this model, although we cannot completely exclude that other kinases related or unrelated to the IKK complex may functionally compensate for IKK2 in Ikk2 $\Delta$ hepa mice.
Our results differ from those in a recent study by Maeda et al. that examined the effects of IKK2 knockout in LPS- and ConAmediated liver injury. In agreement with our results, they found that LPS treatment did not result in higher mortality or significant liver injury in mice lacking IKK2, although NF-KB activation in response to TNF- $\alpha$ or LPS was strongly attenuated (30). Therefore, the authors concluded that inhibition of NF- $\mathrm{KB}$ activity is not sufficient for induction of liver failure even in the presence of very high levels of circulating TNF- $\alpha$. Our results argue against this hypothesis since inhibition of NF- $\mathrm{\kappa B}$ activity correlated tightly with hepatocyte injury due to TNF- $\alpha$. More importantly, inhibition of NF- $\kappa B$ activation upon TNF- $\alpha$ stimulation in Nemo $\Delta$ mice led to a very rapid death in those animals due to hepatic failure whereas $I k k 2 \Delta$ hepa and $I k k 2 \Delta$ mice were able to activate NF-кB upon TNF- $\alpha$ stimulation and were protected from liver failure. Thus, it is likely that induction of the key survival genes that protect against liver failure upon TNF- $\alpha$ and that can be blocked, e.g., by GalN depend on a functional IKK complex that mediates nuclear NF-кB translocation.

The difference in the ability of TNF- $\alpha$ to activate NF- $\kappa$ B shown in the above-mentioned study and our results might in part be explained by a difference in the loxP construct of the 2 mouse models. The mouse of Maeda et al. has exon 3 flanked by loxP sites, which leads to a knockout of the kinase domain, whereas 
our mouse has exons 5 and 6 floxed, introducing a stop codon which leads to a null allele. It is possible that a truncated protein is still expressed in Maeda's study that can mimic at least in part a dominant-negative effect. Whereas in Maeda's study, mice lacking functional IKK2 in the liver were highly susceptible to liver destruction following ConA-induced $\mathrm{T}$ cell activation, in our study Ikk2 $\Delta$ hepa mice did not display this phenotype.

Next to its function in the TNF- $\alpha$ pathway, we could define a novel property of IKK2 in the more complex model of I/R injury in the liver. Instead of linear apoptotic signaling, it has been proposed that I/R injury consists of 2 different phases, 1 displaying acute cellular injury and a secondary, subacute phase that results from inflammatory responses (37-39). Up to now, it has been unclear how NF- $\kappa B$ is activated in this model. Whereas TNF- $\alpha$ stimulation

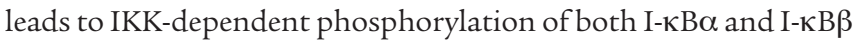
on serine residues, recent studies have suggested that, during $I / R$ injury, NF-кB is activated by c-Src dependent tyrosine phosphory-

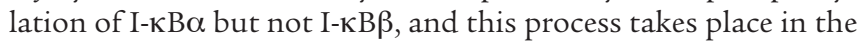
absence of I- $\kappa B \alpha$ ubiquitin-dependent degradation $(21,33)$. Thus, the authors have assumed that NF- $\kappa \mathrm{B}$ is activated independently of the IKK complex during I/R. We demonstrate that activation of $N F-\kappa B$ after $I / R$ is dependent on IKK2. Nevertheless, our results in the TNF- $\alpha$ model indicate that NF- $\kappa \mathrm{B}$ activation after I/R happens in a manner different than after TNF- $\alpha$ stimulation and indeed might involve a specific interaction of IKK2 with, e.g., the c-Src pathway that cannot be replaced by an alternative compound of the IKK complex. Since some TNF- $\alpha$ is still present in Ik $2 \Delta$ hepa mice (Figure 6C), one would expect that this would still lead to NF- $\kappa \mathrm{B}$ activation by the canonical, TNF-R1-mediated pathway with regard to our results in the TNF- $\alpha$-injection model. However, the TNF- $\alpha$ that is detected by immunohistochemistry is probably cell-bound TNF- $\alpha$ that acts mainly through TNF-R2 and activates different pathways (30). Moreover, the amounts of free TNF- $\alpha$ detectable in mice after $\mathrm{I} / \mathrm{R}$ were much lower than after injection with recombinant TNF- $\alpha$ (data not shown) and thus probably not

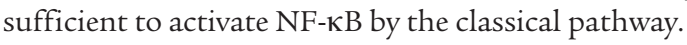

It has also been unclear whether NF- $\mathrm{BB}$-dependent signaling plays a protective or damaging role in I/R injury. Since NF-кB maintains both proinflammatory and antiapoptotic properties in the liver (40), inhibition of its function after I/R might turn the fate of hepatocytes in either direction. In fact, a recent study showed that inhibition of IKK2/NF-KB-dependent signaling in gut cells prevented a systemic inflammatory response but resulted in severe apoptotic damage to the reperfused intestinal mucosa (41). We could demonstrate that inhibition of IKK2-dependent $N F-\kappa B$ activation protects against liver injury due to $I / R$ in the liver. This goes along with decreased expression of inflammatory cytokines such as TNF- $\alpha$ and NO-regulating proteins.

By using conditional knockout mice for IKK subunits with targeted deletions in the liver, we could demonstrate a functional difference between the role of IKK2 in TNF- $\alpha$-induced apoptosis on one hand and inflammation and necrosis due to $I / R$ on the other hand. This unexpected finding makes this molecule an attractive target for pharmacological intervention. During recent years, numerous strategies have been proposed for prophylaxis and treatment of $\mathrm{I} / \mathrm{R}$ injury to the liver, aiming at the different pathophysiological factors of this process (42). In this study, we demonstrated that AS602868, a novel chemical inhibitor of IKK2, dramatically reduces inflammation and liver injury after I/R. In contrast, AS602868 did not influence NF-KB activation nor did it lead to increased liver injury upon TNF- $\alpha$ stimulation, which strongly supports our data from the knockout mice. In fact, this protective effect in $\mathrm{I} / \mathrm{R}$ injury with no apparent harmful effect in TNF- $\alpha$-mediated signaling highlights the potential specificity of this treatment option for hepatic I/R injury compared with a possible molecular inhibition, e.g., at the level of TNF- $\alpha$ or NF-KB directly. AS602868 therefore might prove to be a very promising and safe new agent, probably applicable in decreasing liver injury, e.g., after tissue resection (Pringle maneuver), hemorrhagic shock, or in the field of liver transplantation surgery. It would also probably be beneficial in preventing tissue injury due to ischemia in other organs such as the brain or heart.

\section{Methods}

Generation of conditional Ikk2 and Nemo knockout mice. Mice carrying the loxPsite-flanked (floxed [f]) Ikk2 gene $\left(I k k 2^{\mathrm{f} / \mathrm{f}}\right)$ and the floxed Nemo gene $\left(N e m o^{\mathrm{f} / \mathrm{f}}\right.$ ) were generated as described $(24,26)$. Ikk2 ${ }^{\mathrm{f} / \mathrm{f}}$ mice were either crossed to Alfp-cre transgenic mice (25) to generate a hepatocyte-specific knockout

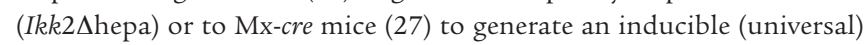
knockout $\left(\operatorname{Ikk2\Delta )}\right.$. Nemo ${ }^{\mathrm{f} / \mathrm{f}}$ mice were crossed to Mx-cre mice (Nemo $\left.\Delta\right)$. For induction of the deletion, $\mathrm{Mx}$-cre Ikk2 $2^{\mathrm{f} / \mathrm{f}}$ and $\mathrm{Mx}$-cre $\mathrm{Nemo}^{\mathrm{f} / \mathrm{f}}$ mice as well as the respective cre-negative control mice were injected i.p. with $13 \mathrm{mg} /$ $\mathrm{kg}$ poly I/C (Pharmacia Corp.) at the age of 6 weeks. Genotyping for the cre-transgene was performed as described (43). Animal experiments were approved by the district government of Lower Saxony, Germany. For all experiments performed with genetically modified animals, cre-negative littermates were used as controls.

Liver injury and I/R models. All experiments were performed on pathogenfree male mice between 8 and 10 weeks of age. Recombinant murine TNF- $\alpha$ (G.R. Adolf, Bender \& Co. GmbH, Vienna, Austria) was injected i.v. in pyrogen-free saline at a concentration of $6 \mu \mathrm{g} / \mathrm{kg}$. LPS (Escherichia coli O55:B5) (Sigma-Aldrich) was administered i.p. at a concentration of $20 \mathrm{mg} / \mathrm{kg}$. LPS and GalN (Sigma-Aldrich) were coadministered i.p. at concentrations of $100 \mu \mathrm{g} / \mathrm{kg}$ (LPS) and $800 \mathrm{mg} / \mathrm{kg}$ (GalN). ConA (Sigma-Aldrich) was injected i.v. at $10 \mathrm{mg} / \mathrm{kg}$. Anti-Fas Monoclonal Antibody (Jo-2) (BD Biosciences - Pharmingen) was injected i.v. at $0.5 \mathrm{mg} / \mathrm{kg}$.

For hepatic I/R experiments, mice were anesthetized by inhalation with isoflurane. The abdominal cavity was opened through a midline incision, and the liver was freed from its ligaments. The caudate lobes were resected. The portal triad was identified. Inflow occlusion to the median and left lobes was performed by placing a microvascular clamp (Aesculap) on the respective branches, preserving adequate blood flow to the right lobes. Sixty minutes after clamping, reperfusion was initiated by removing the clamp. At different time points after reperfusion, blood was taken from the animals and serum was prepared for further analysis. AST and ALT activities were measured by standard procedures. Alternatively, mice were sacrificed, and the median and left lobes were removed, rinsed in ice-cold PBS, and taken for preparation of cellular and nuclear protein extracts or histological slides.

For experiments with the chemical compound AS602868 (kindly provided by Serono), we used pathogen-free male C57BL6 mice. Mice received an oral administration of $150 \mu \mathrm{l}$ of the IKK2 inhibitor $(10 \mu \mathrm{g} / \mathrm{g}$ body weight) or vehicle $(0.5 \%$ carboxymethylcellulose/Tween $0.25 \%) 20$ hours and 2 hours before the procedure.

Isolation of hepatocytes, Kupffer cells, and adenoviral infection. Primary mouse hepatocytes were isolated by collagenase perfusion. Mouse liver was perfused retrograde with Krebs Ringer buffer followed by perfusion of the liver with collagenase solution. Isolated hepatocytes were washed intensely with PBS. After determination of viability (>95\%), $8 \times 10^{5}$ cells were plated on 6-cm dishes in DMEM (Sigma-Aldrich) containing 
$10 \%$ fetal calf serum in addition to a separate combination of penicillin and streptomycin. The medium was changed after 4 hours. To isolate Kupffer cells, we followed a method described by Knolle et al. (44), combined with magnetic cell sorting. In brief, after retrograde liverperfusion, cells were subjected to density-gradient centrifugation on a Nycodenz gradient (Sigma-Aldrich) (final density of cell solution: 1.089 $\mathrm{g} / \mathrm{cm}^{3}$ ) at $1400 \mathrm{~g}$ for 25 minutes. After washing in Gey's balanced salt solution (Sigma-Aldrich), cells from the top layer were subjected to magnetic labeling with CD11b MicroBeads (\#130-049-601) and positive selection with MACS LS columns (Miltenyi Biotec), according to manufacturer's instructions. After 2 days, cells were fixed in Acetone and stained. Additionally, cells were stimulated with LPS $(1 \mu \mathrm{g} / \mathrm{ml}$ medium $)$ for 1 hour and then fixed.

Generation of adenovirus serotype 5 containing the LacZ gene or a catalytically inactive IKK2 mutant and preparation of viral stocks was described previously $(31,45)$. Cells were infected in DMEM with 20 PFUs of the recombinant adenovirus for 12 hours, then treated with TNF- $\alpha(30 \mathrm{ng} / \mathrm{ml})$.

Southern blot analysis and duplex RT-PCR. Liver tissue was digested with proteinase $\mathrm{K}$ (Roche Diagnostics Corp.) and this solution treated with saturated $\mathrm{NaCl}$ solution, and DNA was isolated by isopropanol precipitation. DNA was Stu1 digested, and Southern blot analysis was performed as described (43). Blots were hybridized with a probe that recognizes a Stu1 fragment from the deleted and undeleted Ikk2 sequence.

Total RNA from mouse livers was isolated by RNA-clean (HYBAID Ltd.). First strand synthesis was performed with Oligo $\mathrm{dT}$ primers and reverse transcriptase (Invitrogen Corp.). RNA $(5 \mu \mathrm{g})$ from mouse livers served as templates. The following primers were used: Ikk2 sense: 5'-GGAGTACTGCCAAGGAGGAGAT- 3 ' and antisense: $5^{\prime}$-ACAGGCTGCCAGTTAGGGAGGAAG-3'; Nemo sense: 5'-AGCGCTGCCTGGAAGAGAATCAAG-3' and antisense: 5'-ACCTGGACGCTGTGCTGCTGCTGT-3'; gapdh sense: 5'-ACGGGCAAATTCAACGGCACAGTCA-3' and antisense: 5'-CATTGGGGGTAGGAACACGGAAGG-3'. For the duplex PCR approach, combinations of the Ikk2/gapdh or Nemo-gapdh primers were used as indicated. After 20 cycles, aliquots were taken to verify the exact GAPDH ratios.

IP/Western blot analysis. Cellular protein extracts from mouse livers and primary hepatocyte cultures were prepared as described (46). Protein extracts were IP with polyclonal antibodies against NEMO (sc-8330) or IKK1 (sc-7184) (Santa Cruz Biotechnology), incubated with protein A/G beads (Oncogene Science), washed, and resuspended in Laemmli sample buffer.

For Western blot analysis, protein extracts were subjected to SDS-polyacrylamide-gel electrophoresis and blotted as described (46). Membranes were probed with the following antibodies: anti-IKK $\alpha$ (IMG-136), antiIKK $\beta$ (IMG-129) (Imgenex Corp.), anti-NEMO (sc-8330), anti-I-KB $\alpha$ (sc-371), anti- $\alpha$-tubulin (sc-8035), anti-JNK1 sc-474-G) (Santa Cruz Biotechnology, Inc.), anti-phospho-I-kB $\alpha$ (9241), anti-phospho-SAPK/JNK (\#9251), and anti-phospho-j-cun (Ser63) (9261) (Cell Signaling Technology). As secondary antibodies, anti-rabbit-IgG (711-035-152) (Jackson ImmunoResearch Laboratories Inc.), anti-mouse-IgG (AQ 127P), or antigoat-IgG (AP 106B) (Chemicon International) was used.

Gel-retardation assay (electromobility shift assay). For gel-retardation assays, liver nuclear extracts were prepared and binding reaction was performed as described (45). Free DNA and DNA protein complexes were resolved on a $6 \%$ polyacrylamide gel. A ${ }^{32} \mathrm{P}$-labelled oligonucleotide representing an NF- $\kappa$ B consensus site ( $5^{\prime}$-TAGTTGAGGGGACTTTCCCAGGCA- 3 ') was used as probe. For super shift, antibodies against p50 (sc-114X), p65 (sc-109X), and c-Rel (sc-71X) (Santa Cruz Biotechnology Inc.) were used.

Caspase assay and IKK1 assay. Evaluation of caspase activity was performed as described previously (47). For the IKK assay, $300 \mu \mathrm{g}$ protein extract was IP with $2 \mu$ l anti-Nemo antibody NEMO (sc-8330) (Santa Cruz Biotechnology Inc.), and the Kinase assay was performed as described previously (31), using a glutathione-S-transferase-I-KB (1-54) substrate.

TUNEL assay and immunohistochemistry. The TUNEL test was performed using the in situ cell death detection Kit POD (Roche Diagnostics Corp.) according to the instructions of the manufacturer, using a fluorescence microscope. H\&E stainings were performed using a standard protocol for cryosections. Immunohistochemistry was performed on frozen sections or isolated Kupffer cells fixed on slides using rabbit polyclonal antibodies against TNF- $\alpha$ (sc-8301), IKK $\alpha / \beta$ (sc-7607; Santa Cruz Biotechnology, Inc.), iNOS (610332; BD Transduction Laboratories; BD Biosciences - Pharmingen), or rat IgG2a antibody against the F4/80 antigen for characterization of mouse macrophages (BM 4007) (Acris Antibodies GmbH). Primary antibodies were used at a dilution of 1:10 (TNF- $\alpha$, iNOS), 1:50 (IKK1/2), or 1:500 $(\mathrm{F} 4 / 80)$ and incubated for 30 minutes at room temperature. The staining was visualized with the polyclonal Enhanced Vision reaction (Dako Corp.).

Statistical analysis. Data are expressed as mean \pm SD determined by 1 -way analysis of variance followed by Scheffe's $F$ test to determine significance.

\section{Acknowledgments}

This work was supported by a grant from the Deutsche Forschungemeinschaft (DFG TR285/4-2). The authors are grateful to the following people for valuable discussion and technical assistance: M. Karin (University of San Diego, San Diego, California, USA), B. Bennett (Celgene Corp., San Diego, California, USA), E. Wagner (Institute of Molecular Pathology, Vienna, Austria), R. Schwabe (College of Physicians and Surgeons, Columbia University, New York, New York, USA), H. Rüdiger and P. A. Clavien (University of Zurich, Zurich, Switzerland), W. Müller (Gesellschaft für Biotechnologische Forschung, Braunschweig, Germany), P. Knolle (Institute of Molecular Medicine and Experimental Immunology, University of Bonn, Bonn, Germany), and F. Tacke, N. Zschemisch, M. Kracht, H. Buss, and T. Becker (Hannover Medical School, Hannover, Germany).

Received for publication September 29, 2004, and accepted in revised form January 25, 2005.

Address correspondence to: Christian Trautwein, Department of Gastroenterology, Hepatology and Endocrinology, Hannover Medical School, Carl-Neuberg-Strasse 1, 30625 Hannover, Germany. Phone: 49-511-532-6620; Fax: 49-511-532-5692; E-mail: Trautwein.Christian@mh-hannover.de.

Tom Luedde, Ulrike Assmus, and Torsten Wüstefeld contributed equally to this work.
1. Karin, M., and Lin, A. 2002. NF-kappaB at the crossroads of life and death. Nat. Immunol. 3:221-227.

2. Pahl, H.L. 1999. Activators and target genes of Rel/NF-kappaB transcription factors. Oncogene. 18:6853-6866.

3. DiDonato, J.A., Hayakawa, M., Rothwarf, D.M., Zandi, E., and Karin, M. 1997. A cytokine-responsive IkappaB kinase that activates the transcription factor NF-kappaB. Nature. 388:548-554.
4. Karin, M. 1999. How NF-kappaB is activated: the role of the IkappaB kinase (IKK) complex. Oncogene. 18:6867-6874.

5. Mercurio, F., et al. 1997. IKK-1 and IKK-2: cytokineactivated IkappaB kinases essential for NF-kappaB activation. Science. 278:860-866

6. Regnier, C.H., et al. 1997. Identification and characterization of an IkappaB kinase. Cell. 90:373-383.

7. Mercurio, F., et al. 1999. IkappaB kinase (IKK)- associated protein 1 , a common component of the heterogeneous IKK complex. Mol. Cell. Biol. 19:1526-1538.

8. Rothwarf, D.M., Zandi, E., Natoli, G., and Karin, M. 1998. IKK-gamma is an essential regulatory subunit of the IkappaB kinase complex. Nature. 395:297-300.

9. Yamaoka, S., et al. 1998. Complementation cloning of NEMO, a component of the IkappaB kinase 
complex essential for NF-kappaB activation. Cell. 93:1231-1240.

10. Zandi, E., Chen, Y., and Karin, M. 1998. Direct phosphorylation of IkappaB by IKKalpha and IKKbeta: discrimination between free and NF-kappaB-bound substrate. Science. 281:1360-1363.

11. Delhase, M., Hayakawa, M., Chen, Y., and Karin, M. 1999. Positive and negative regulation of IkappaB kinase activity through IKKbeta subunit phosphorylation. Science. 284:309-313.

12. Woronicz, J.D., Gao, X., Cao, Z., Rothe, M., and Goeddel, D.V. 1997. IkappaB kinase-beta: NF-kap$\mathrm{paB}$ activation and complex formation with IkappaB kinase-alpha and NIK. Science. 278:866-869.

13. Zandi, E., Rothwarf, D.M., Delhase, M., Hayakawa, M., and Karin, M. 1997. The IkappaB kinase complex (IKK) contains two kinase subunits, IKKalpha and IKKbeta, necessary for IkappaB phosphorylation and NF-kappaB activation. Cell. 91:243-252.

14. Hu,Y., et al. 1999. Abnormal morphogenesis but intact IKK activation in mice lacking the IKKalpha subunit of IkappaB kinase. Science. 284:316-320.

15. Takeda, K., et al. 1999. Limb and skin abnormalities in mice lacking IKKalpha. Science. 284:313-316.

16. Li, Q., Van Antwerp, D., Mercurio, F., Lee, K.F., and Verma, I.M. 1999. Severe liver degeneration in mice lacking the IkappaB kinase 2 gene. Science. 284:321-325.

17. Li, Z.W., et al. 1999. The IKKbeta subunit of IkappaB kinase (IKK) is essential for nuclear factor kap$\mathrm{paB}$ activation and prevention of apoptosis. J. Exp. Med. 189:1839-1845.

18. Tanaka, M., et al. 1999. Embryonic lethality, liver degeneration, and impaired NF-kappa B activation in IKK-beta-deficient mice. Immunity. 10:421-429.

19. Rudolph, D., et al. 2000. Severe liver degeneration and lack of NF-kappaB activation in NEMO/ IKKgamma-deficient mice. Genes Dev. 14:854-862.

20. Luedde, T., Liedtke, C., Manns, M.P., and Trautwein, C. 2002. Losing balance: cytokine signaling and cell death in the context of hepatocyte injury and hepatic failure. Eur. Cytokine Netw. 13:377-383.

21. Fan, C., Li, Q., Ross, D., and Engelhardt, J.F. 2003. Tyrosine phosphorylation of I kappa B alpha activates NF kappa B through a redox-regulated and c-Src-dependent mechanism following hypoxia/ reoxygenation. J. Biol. Chem. 278:2072-2080.
22. Zwacka, R.M., et al. 1998. Redox gene therapy for ischemia/reperfusion injury of the liver reduces AP1 and NF-kappaB activation. Nat. Med. 4:698-704.

23. Zwacka, R.M., Zhang, Y., Zhou, W., Halldorson, J., and Engelhardt, J.F. 1998. Ischemia/reperfusion injury in the liver of $\mathrm{BALB} / \mathrm{c}$ mice activates AP-1 and nuclear factor kappaB independently of IkappaB degradation. Hepatology. 28:1022-1030.

24. Pasparakis, M., et al. 2002. TNF-mediated inflammatory skin disease in mice with epidermis-specific deletion of IKK2. Nature. 417:861-866.

25. Kellendonk, C., Opherk, C., Anlag, K., Schutz, G., and Tronche, F. 2000. Hepatocyte-specific expression of Cre recombinase. Genesis. 26:151-153.

26. Pasparakis, M., Schmidt-Supprian, M., and Rajewsky, K. 2002. IkappaB kinase signaling is essential for maintenance of mature B cells. J. Exp. Med. 196:743-752.

27. Kuhn, R., Schwenk, F., Aguet, M., and Rajewsky, K. 1995. Inducible gene targeting in mice. Science. 269:1427-1429.

28. Tiegs, G., Hentschel, J., and Wendel, A. 1992. A T celldependent experimental liver injury in mice inducible by concanavalin A. J. Clin. Invest. 90:196-203.

29. Trautwein, C., et al. 1998. Concanavalin A-induced liver cell damage: activation of intracellular pathways triggered by tumor necrosis factor in mice. Gastroenterology. 114:1035-1045.

30. Maeda, S., et al. 2003. IKKbeta is required for prevention of apoptosis mediated by cell-bound but not by circulating TNFalpha. Immunity. 19:725-737.

31. Schwabe, R.F., Bennett, B.L., Manning, A.M., and Brenner, D.A. 2001. Differential role of I kappa B kinase 1 and 2 in primary rat hepatocytes. Hepatol ogy. 33:81-90.

32. Jaeschke, H. 2003. Molecular mechanisms of hepatic ischemia-reperfusion injury and preconditioning. Am. J. Physiol. Gastrointest. Liver Physiol. 284:G15-G26.

33. Fan, C., et al. 2004. IkappaBalpha and IkappaBbeta possess injury context-specific functions that uniquely influence hepatic NF-kappaB induction and inflammation. J. Clin. Invest. 113:746-755. doi:10.1172/JCI200417337.

34. Rudiger, H.A., and Clavien, P.A. 2002. Tumor necrosis factor alpha, but not Fas, mediates hepatocellular apoptosis in the murine ischemic liver. Gastroenterology. 122:202-210.
35. Frelin, C., et al. 2003. AS602868, a pharmacological inhibitor of IKK2, reveals the apoptotic potential of TNF-alpha in Jurkat leukemic cells. Oncogene. 22:8187-8194

36. Sage, J., Miller, A.L., Perez-Mancera, P.A., Wysocki, J.M., and Jacks, T. 2003. Acute mutation of retinoblastoma gene function is sufficient for cell cycle re-entry. Nature. 424:223-228.

37. Jaeschke, H., Smith, C.V., and Mitchell, J.R. 1988. Reactive oxygen species during ischemia-reflow injury in isolated perfused rat liver. J. Clin. Invest. 81:1240-1246.

38. Jaeschke, H., and Farhood, A. 1991. Neutrophil and Kupffer cell-induced oxidant stress and ischemia-reperfusion injury in rat liver. Am. J. Physiol. 260:G355-G362.

39. Jaeschke, H. 1991. Reactive oxygen and ischemia/ reperfusion injury of the liver. Chem. Biol. Interact. 79:115-136.

40. Fan, C., Yang, J., and Engelhardt, J.F. 2002. Temporal pattern of NFkappaB activation influences apoptotic cell fate in a stimuli-dependent fashion. J. Cell Sci. 115:4843-4853.

41. Chen, L.W., et al. 2003. The two faces of IKK and NFkappaB inhibition: prevention of systemic inflammation but increased local injury following intestinal ischemia-reperfusion. Nat. Med. 9:575-581.

42. Arii, S., Teramoto, K., and Kawamura, T. 2003. Current progress in the understanding of and therapeutic strategies for ischemia and reperfusion injury of the liver. J. Hepatobiliary Pancreat. Surg. 10:189-194.

43. Wuestefeld, T., et al. 2003. Interleukin-6/glycoprotein 130-dependent pathways are protective during liver regeneration. J. Biol. Chem. 278:11281-11288.

44. Knolle, P., et al. 1995. Human Kupffer cells secrete IL-10 in response to lipopolysaccharide (LPS) challenge. J. Hepatol. 22:226-229.

45. Lüdde, T., et al. 2001. Ras adenoviruses modulate cyclin E protein expression and DNA synthesis after partial hepatectomy. Oncogene. 20:5264-5278.

46. Luedde, T., et al. 2003. p18(INK4c) collaborates with other CDK-inhibitory proteins in the regenerating liver. Hepatology. 37:833-841.

47. Luedde, T., et al. 2004. C/EBP beta isoforms LIP and LAP modulate progression of the cell cycle in the regenerating mouse liver. Hepatology. 40:356-365. 